\title{
Investigating the Impact of Integrated Supply Chain Forecasting on the Supply Chain Performance: Empirical Study from the FMCGs Sector in Egypt 1
}

\author{
Mahira M. Abdel-shafie ${ }^{2}$
}

\author{
Dr. Sara H. Elgazzar ${ }^{3}$
}

\begin{abstract}
Organizations have become progressively aware of the fact that the success and sustainability of their own business are strongly dependent on the collaboration and coordination with their suppliers and customers; particularly in terms of information sharing. Companies that manage the Supply Chain (SC) as a single entity and guarantee the suitable use of forecasting tools and techniques in order to meet the demand and needs of the market will not get left behind in the fight for survival. This research aims at proposing an applied framework linking and showing the impact of integrated SC forecasting on the SC performance. An empirical study is conducted on the Fast Moving Consumer Goods (FMCGs) sector in Egypt in two multinational companies: Procter \& Gamble and Nestle, and one national company: Sakr Group which is currently engaged in collaborative forecasting with its SC partners. The empirical study first started with semi-structured interviews to provide an overview of the FMCGs supply chain and analyze its characteristics in the Egyptian market. Then, a semi-structured survey is designed and carried out to gain an insight into the implementation and the relevance of the variables enhancing integrated SC forecasting in the Egyptian FMCGs industry. Based on the survey results, an applied framework is developed to link the integrated SC forecasting to supply chain performance. Finally, in-depth interviews are carried out to verify the relationship between integrated SC forecasting and SC performance based on the applied framework. The results identify Information Sharing, Information Quality and Information Technology as the main variables to implement integrated SC forecasting. In addition, the results prove that an integrated SC

${ }^{1}$ Received in 11/1/2021, accepeted in 23/2/2021.

${ }^{2}$ Mahira Mostafa Abdel-shafie is currently Teaching Assistant at College of International Transport and Logistics, Arab Academy for Science, Technology and Maritime Transport (Ma mostafa_1@hotmail.com)

${ }^{3}$ Dr. Sara Elgazzar is currently Associate Professor at College of International Transport and Logistics, Arab Academy for Science, Technology and Maritime Transport (sara.elgazzar02@gmail.com)
\end{abstract}


forecasting has a positive impact on the SC performance, and hence on the overall organization performance.

Keywords: Integrated Supply Chain Forecasting - Supply Chain Performance - Supply Chain Integration - FMCGs Sector-Egypt.

\section{1- Introduction}

Competition is no longer between companies, but rather between Supply Chains (SCs) as globalization has led to an increased demand for product assortment as well as shorter product life-cycles. This highlights the fact that the most significant benefit of Supply Chain Management (SCM) is the ability to design products faster, with higher qualities and lower costs as compared to a single company (Näslund and Hulthen, 2012; Ayoub et al., 2017).

SCM has been considered as an effective strategy for organizations that rationalize internal and external activities to improve performance and effectiveness. Nowadays, organizations are competing on supply chains for providing rapid delivery, innovative various ranges of products, and services to satisfy customer needs and create value for them (Khanuja and Kumar Jain, 2019).

A well-integrated SC is one of the primary business strategies adopted to enhance SC performance. Integrating the SC requires philosophical, operational and system changes. It embraces and links all of the internal and external partners in the chain; as it integrates, coordinates and monitors the flow of materials, information and capital as well. Real-time information exchange with suppliers in the upstream and with customers in the downstream will create an opportunity where optimization can take place and participate in enhancing overall performance (Lee et al, 2007).

When demand is disconnected from supply in the form of stocks of inventory both within and between organizations and their trading partners, and shared with isolated forecasting and planning, an organization faces a tough challenge to operate. In the meantime, competing SCs that manage through collaboration to integrate supply and demand can deliver significantly improved performance, and benefit yet more from closer relationships that they substitute more opportunities for greater improvement (Barratt, 2004). Therefore, it is 
of value to investigate the impact of integrated SC forecasting on SC performance. This research sheds the light on the importance of collaborative forecasting in the SC through investigating how it can influence SC performance. The paper aims at proposing a framework linking collaborative forecasting to the SC performance in order to enhance overall organization performance. To show the applicability of the proposed framework, an empirical study on Egyptian FMCGs sector is conducted and concluded with procedures to identify challenges encountered during the process of adopting SC integrated forecasting.

\section{2- Literature Review}

SCM has recently become a prevalent research topic and has gained a huge consideration from both academics and business experts as the SCs are a key factor in many successful business processes (Okongwu et al, 2015). LeMay et al. (2017) state that it is the coordination of a network through organizations and individuals to get, use, and deliver material goods, to acquire and distribute services, and to make their offerings available to markets, customers, and clients (LeMay et al., 2017).

Accordingly, an adoption of an integrated approach throughout the SC needs a trade-off between independence and control to which the balance is unique between each SC partner (Graham and Hardaker, 2000). In addition, Supply Chain Integration (SCI) seeks to minimize nonvalue-added activities as this drives investment cost, operating cost, and time out of the SC process and adds greater customer responsiveness and flexibility into the SC, cutting costs and thus improving organization performance and cost competitiveness (Ayoub et al., 2017).

Simatupang and Sridharan (2005) identify SC collaboration as a fundamental agreement among SC partners to integrate their resources for joint gain to create a competitive advantage and higher profits than what can be achieved by acting alone (Bowersox et al., 2003).The beginning of SC collaboration forms the need to pay special attention to the understanding of collaboration in order to prepare chain members to create collaborative efforts successfully (Lambert et al., 2004). 


\section{2-1 Integrated Supply Chain Practices}

Supply chain processes and their effective integration, as defined by Chen et al. (2009), refer to "linking major business functions and business processes within and across firms into a cohesive and highperforming business model". Li et al., (2009) find that SC integration is significantly related to SC performance. However, older SC initiatives had gaps in their practices since financial plans took priority over forecast, resulting in high-inventory levels, lower order-fill rates, and increased advanced activities (Attaran and Attaran, 2007). Most authors have empirically investigated Supply Chain Practices (SCPs) that enhance the collaboration between SC partners from different perspectives; with an integrated perspective capturing all elements. The following table summarizes the most commonly used SCPs that have been attempted by previous research and studies to improve SCM integration.

Table 1: The main publications on dimensions of integrated supply chain practices

\begin{tabular}{|l|l|}
\hline \multicolumn{1}{|c|}{$\begin{array}{c}\text { SCPs used to improve SCM } \\
\text { integration }\end{array}$} & \multicolumn{1}{|c|}{ Authors } \\
\hline \multirow{3}{*}{ - Information Sharing } & $\begin{array}{l}\text { Tan, 2001; Sahay and Mohan, 2003; Barratt, } \\
\text { 2004; Li et al., 2006; Sundram et al., 2011; } \\
\text { Prajogo and Olhager, 2012; Eksoz et al, } \\
\text { 2014; Gandhi, 2016 }\end{array}$ \\
\hline \multirow{3}{*}{ - Information Quality } & $\begin{array}{l}\text { Moberg et al., 2002Sahay and Mohan, 2003; } \\
\text { Li et al., 2006; Sundram et al., 2011, } \\
\text { Marinagi et al, 2015 }\end{array}$ \\
\hline \multirow{3}{*}{ - Information Technology } & $\begin{array}{l}\text { Donlon, 1996; Sahay and Mohan, 2003; Sheu } \\
\text { et al., 2006; Prajogo and Olhager, 2012; } \\
\text { Sadraoui \& Mchirgui, 2014 }\end{array}$ \\
\hline
\end{tabular}

As illustrated in Table 1, information sharing, information quality and information technology are the most significant practices of SCM, which work as factors for enhancing the SCM integration and boosting the collaboration between SC members to facilitate the whole process. Each practice is discussed below in more details.

\section{2-1-1 Information sharing}

SCs are nowadays progressively reliant on information sharing, empowered by automation and technologies that have recently emerged. 
In fact, these technologies make the collection and sharing of detailed data and information simpler and faster, and supply chains are increasingly finding themselves operating in a connected global environment (Colicchia et al, 2019). Information is often unpredictable between the upstream and downstream of SC partners (Prajogo and Olhager, 2012). SC members may have to forecast their market demands based on incomplete information. Therefore, all members require keeping higher stock for their products to immediately respond to market changes. As a result; this would cause the increase of production cost and the reduction of profit margin for members. This is well known as the "bullwhip effect". Thus, many studies have highlighted that information sharing is one of the most critical factors for an effective SC practice (Wu et al, 2014).

Information sharing requires organizations to exchange tactical SC information and not only transactional data, such as materials or product orders. The tactical SC information offers control to the SC partner for making strategic decisions in their operations (Li et al., 2006). For instance, point-of-sale history helps suppliers to successfully forecast demand, which subsequently improves service level and responsiveness to their customers. Similarly, real-time inventory position helps suppliers to plan their replenishment and delivery schedules; hence improving service levels and reducing inventory costs. While information is gathered, disseminated, and shared throughout the SC using Intranets and Extranets, information quality should also be reserved (Marinagi et al, 2015).

\section{2-1-2 Information Quality}

Information Quality (IQ) is a multidimensional concept as English (1999) states that the information quality dimensions could be derived from the seven logistics rights, i.e. the right place, time, quantity, quality, price, condition and customer. While Lindau and Lumsden (1993) focus on three information quality dimensions resulting from the rights; correct information which refers to the right information in the right condition, timely information, and complete information. Moberg et al. (2002) discuss accuracy, timeliness and proper formatting as important 
qualities of information. They state that information has little value if it has poor reliability and validity.

Marinagi et al. (2015) propose a research framework that provides empirical evidence that information sharing acts as the mediator between information quality and SC performance, while Forslund and Jonsson (2007) show the impact of supplier access to customer forecast information, and the quality of such information on SC performance. Lu (2015) states that the quality of information depends on the credibility of the SC members and how they want to provide the information. They may provide artificial information and hide the true picture, which will at the end impact the degree of accuracy of the forecasts generated from such information.

This review reveals that the quality of information put through the forecasting process is the first step which should be taken, but not the only one! Sharing the right, qualified and related information in a wide range with the highest possible quality does not automatically lead to an accurate forecast outcome, but how to analyse this information, how to understand it and how to use and develop it are some key determinations in producing accurate forecast. Without the information technology (IT) capabilities, these processes cannot be done between SC members in an effective and efficient way.

\section{2-1-3 Information technology}

Today's information technology is infusing the SC at every point, transforming the way exchange-related activities are accomplished and the nature of the links between them. The advances of information technology are responsible for information sharing as the key feature of SC collaboration. Information technology also improves SC efficiency by providing real-time information regarding product availability, inventory level, shipment status, and production supplies (Sadraoui and Mchirgui, 2014).

Rezaei et al. (2017) state that due to current improvements in information and communication technology and its extensive usage in both services and industry, the capability of classifying, recording and updating data has been increased and the ability of adjusting processes 
and making adaptive decisions is therefore boosted. In advanced SCMs, real-time information tracing is of the utmost crucial concerns and it is becoming more and more vital, since it is capable of accelerating the controllers' response to SCM decisions, and therefore enhancing the SCM efficiency (Rezaei et al., 2017).

Sheu et al. (2006) proposes a conceptual relationship model, including a long-term relationship, SC architecture (including for e.g. information sharing and IT capabilities), supplier-retailer collaboration, and performance. They conclude that better IT capabilities as well as better communication contribute to a better platform for both parties to be involved in SC coordination, participation, and problem-solving activities. Li et al. (2006) find that IT competencies and information sharing have a major direct effect on the SC integration of logistics systems, and an indirect one on performance. Prajogo and Olhager (2012) investigate the integrations of both information technology, sharing and material flows between SC partners and their effect on operational performance. Specifically, they examine the role of long-term supplier relationship as the driver of the integration.

Despite the fact that the technological aspect of information integration is critical, it is the symmetry, the quantity and the quality of the information shared which really matter. Information sharing can be applied using modern IT techniques to enable the organization of processes among members, smoothing supplier-customer interactions and minimizing transaction cost. Efficient and user-friendly IT applications may improve information sharing as well (Yang and Maxwell, 2011).

As shown in the review, most studies have focused on three factors that lead SC practices to collaborate (information sharing, information quality and information technology) to achieve integrated SC forecasting positively impacting SC performance. The demand from the final consumer is the force which drives the activities in the SC. Each of the links in the SC functions is in reaction to actual or expected demand from the consumer at the end of the chain. The level of accuracy and efficiency with which this demand is linked up and down the chain is directly connected to inventory and customer service levels. Forecasting and 
demand planning are therefore a key factor in the successful implementation of an SCM strategy (Helms et al, 2000). The next section will prove that practices performed from SC integration, information sharing, information technology and information quality all act as forecasting domains as well.

\section{2-2 Supply Chain Forecasting}

SC planning depends on forecast data that become the base for its production, material sourcing, inventory management, and all other activities in an organization's SC. There are two major ways of forecasting future demand: the first approach is to use existing forecasting methods/techniques, such as moving average and simple exponential smoothing. This approach relies on historical data and mathematical models that are often available through advanced planning and scheduling (APS). The other approach frequently takes demand forecasting data from salespeople (or units) who may (or may not) apply the mathematical forecasting models and collect sales and demand information from customers (Chae, 2009).

The forecasting and planning process in SC is often called sales and operations planning ( $\&$ \& OP). Several studies have emphasized the importance of sharing information between customers and suppliers in SCs, especially point-of-sale (POS) and forecast data (Forslund and Jonsson, 2007).

In the S \& OP process, sharing resources is to share consistent information (e.g. forecast, shipment, inventory, production and purchasing data) and customized information (e.g. factors of demand fluctuation, operational resources and constraints). A collaborative process operation has to do with bonding forecast and plan based on a program established in advance and retracing activities to adjust deviations from forecast and plan when emergencies arise. Through these activities, SC partners can integrate the S \& OP operational process monthly, weekly, and daily (Nakano, 2009).

Attaran (2007) states that the lack of collaborative planning has a major impact on SC performance. SC members cite improvement in forecast accuracy as an important factor for the implementation of collaborative 
practices. One very powerful way to overcome some forecasting challenges is the integration of business logistics systems with the logistics systems of suppliers and customers.

The next section shows that an integrated SC forecasting, based on information sharing, information quality and information technology; the main factors for adjusting forecasting accuracy, leads to a better SC performance.

\section{2-3 Supply Chain Performance Management Systems}

In recent years, a number of organizations have recognized the capabilities of supply chain performance measurement (SCPM). The importance of using efficient and effective methods in SCPM is growing due to economic globalization and business competition (Elgazzar et al., 2011a). In order to be able to assess the success of SCs, an adequate performance measurement system (PMS) needs to be developed (Aramyan et al., 2007; Bititci et al., 1997). To make agile, responsive, sustainable, strong, effective and competitive SCs, organizations need to employ all models and technologies that guarantee productivity and stability (Rezaei et al., 2017). Gunasekaran et al. (2001) explore the importance of a performance measurement system for SC for satisfying the demand of current dynamic market needs, as well as review the development in the area of SC performance measurement (Gunasekaran et al., 2001).

SC performance metrics measure the performance of SC processes in terms of reliability, responsiveness, agility, cost and asset management based on the Supply Chain Operations Reference (SCOR) model standard performance metrics (Elgazzar, 2013). Selecting the most suitable performance measures is challenging due to the complexity and interdependence of SCs.

The SCOR model can be used to describe SCs that are very simple or very complex using a shared set of definitions across different industries. Today, public and private organizations and companies around the world use the model as a foundation for global SC improvement projects (APICS, 2017). 
Many researchers have agreed that there is a significant relationship between SC integration and performance. Table 2 summarizes important aspects of dyadic SC relationships and performance. The empirical findings of this paper contributes to the present research of SC relationship and performance by providing large scale secondary databased evidence and a detailed understanding of how SC partners affect each others' future performance. With the increasing importance of effective SCM, it is important to understand the interdependence and interaction between SC partners.

Table 2: The main publications on relationship between SC performance measurement and integration

\begin{tabular}{|l|l|l|}
\hline \multicolumn{1}{|c|}{ Author } & Year & \multicolumn{1}{c|}{ Method } \\
\hline Gunasekaran et al & 2001 & Conceptual framework \\
\hline Narasimhan and Kim & 2002 & Model \\
\hline Corsten and Felde & 2005 & Empirical case study \\
\hline Aramyan et al & 2007 & Conceptual framework \\
\hline Lee et al & 2007 & Conceptual model \\
\hline Flynn et al & 2009 & $\begin{array}{l}\text { A contingency/ configuration } \\
\text { approach }\end{array}$ \\
\hline Danese and Romano & 2010 & SC performance modeling \\
\hline Prajogo and Olhager & 2012 & Framework \\
\hline Zhao & 2015 & Empirical case study \\
\hline Tsanos and Zografos & 2016 & Conceptual model \\
\hline Michalski et al & 2017 & Conceptual framework \\
\hline Fernandez and Jiménez & 2017 & Systematic review \\
\hline
\end{tabular}

The previous discussion illustrates the significant interrelationship between SCPs, SC integration and SC performance. However, FMCGs face numerous challenges and barriers that prevent them from achieving the benefits of this integration. The following section will discuss the research methodology conducted to conceptualize the research framework, followed by an illustration of an empirical study to verify the proposed framework, identify the main challenges facing collaborated SC forecasting in the Egyptian FMCGs sector, and propose actions to overcome these challenges.

\section{3- Methodology}

The research methodology sets procedures for investigating the relationship between SCPs, integrated SC forecasting and SC performance through answering the following research questions: 
- What are main drivers of SC practices for achieving collaborative forecasting?

- What is the impact of collaborative forecasting on SC performance?

- What are the main obstacles which might prevent companies from achieving integrated SC forecasting in the FMCGs sector?

- What are the proposed actions to overcome these obstacles?

In order to answer the research questions, the following procedures are conducted in three stages as follows:

\section{3-1 Proposing a Framework Identifying SC Practices for Achieving Collaborative Forecasting}

At this stage, a systematic literature review is conducted from 12 papers from the year (2001-2017) to analyze variables that boost SC integration practices (information sharing, information quality and information technology) as shown in Table 1, and to identify factors that enhance forecast accuracy. The variables are classified and filtered to remove the repeated variables and conclude the most effective variables which are linked to SC performance, upon which the framework of linking integrated SC forecasting to SC performance is developed. The research has systematically reviewed the literature following the guidelines by (Tranfield et al., 2003).

As shown in the conceptual framework (Figure 1), integrated SC forecasting mediates the relationship between SCPs and SC performance. SCPs collaborated with information sharing, information quality and information technology serve as independent variables that enhance integrated SC forecasting between SC partners, which leads to improving the dependent variable (i.e. SC performance) measured by: Responsiveness, Reliability, Cost and Asset Management. 


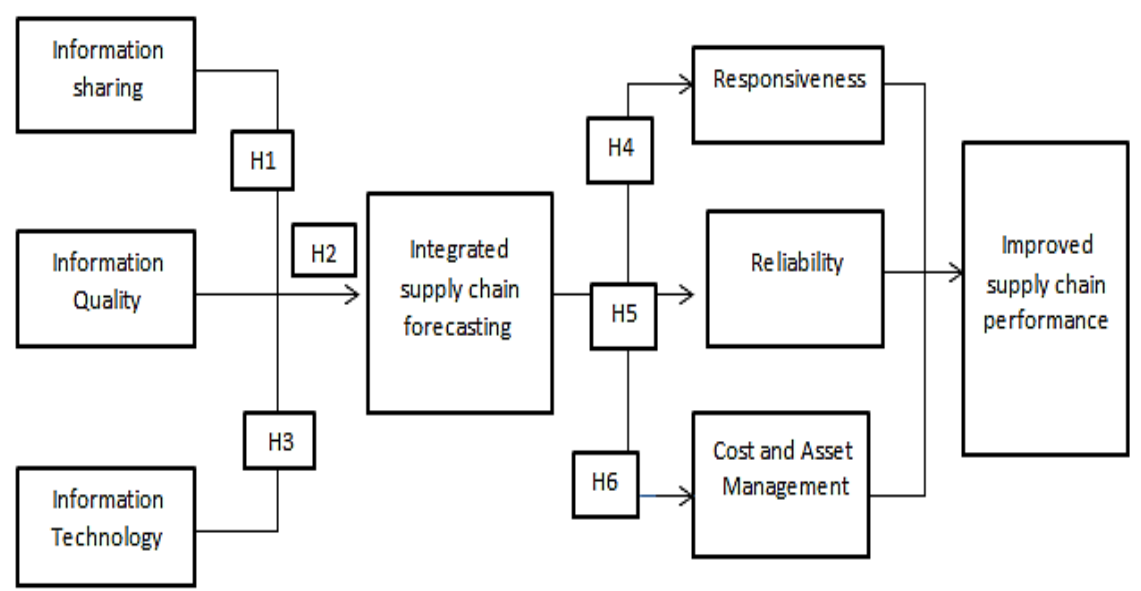

Figure 1: The research framework

Source: Developed by the authors

Based on the developed framework, the following hypotheses are formulated to investigate the impact of SCPs on achieving better integrated forecasting; and accordingly improving SC performance.

H1: Information sharing improves integrated SC forecasting

H2: Information quality improves integrated SC forecasting

H3: Information technology improves integrated SC forecasting

H4: Integrated SC forecasting leads to increased Responsiveness

H5: Integrated SC forecasting leads to Reliability (product availability assurance)

H6: Integrated SC forecasting optimizes Asset and Cost management

\section{3-2 Developing an Applied Framework to Link Integrated SC Forecasting to SC Performance in FMCGs Sector}

To test the research hypotheses and demonstrate the applicability of the proposed framework, an empirical study on the Egyptian FMCGs sector is conducted. At this stage, first a semi-structured interview is conducted with top level management to provide an overview of the FMCGs supply chain and analyse its characteristics in the Egyptian market. Then, the research six hypothesis are tested through a survey instrument based on 
a five-item Likert scale (strongly disagree, disagree, neither agree nor disagree, and strongly agree), measuring the frequency of the practices.

A SCOR model (version 12.0) is employed to establish the survey questions which consist of 30 close-ended questions and 2 opinion questions, aiming at getting an overall view about the FMCGs Company's SC performance, SC practices and the degree of collaboration between trading partners. The questions are divided into two sections; one focused on the three main integrated forecasting practices: information sharing, information quality and information technology, while the other section focuses on SC performance measures by employing the SCOR model's performance matrix: Responsiveness, Reliability, Cost, and Asset Management. Sixty mail-distributed questionnaires were sent to respondents from the Egyptian FMCGs sector to provide their views and opinions concerning SC practices and the performance measurement systems executed in their companies.

In addition to the primary data collected through the survey, a variety of secondary data are collected from statistical records, work process documents, hand-outs and annual reports from the concerned companies. By the end of this stage, a conceptual framework has been verified and turned into an applied framework.

\section{3-3 Investigating the Impact of Integrated SC Forecasting on the SC Performance}

At this stage, it is important to assess the impact of applying the formulated framework on the SC performance. Semi-structured in-depth interviews are conducted with three SC experts to confirm the results based on the previous steps. The interviews, lasting between 30 to 40 minutes, were recorded and transcribed.

\section{4- Empirical Study}

An empirical study on the Egyptian FMCGs sector is conducted. Many explorations are held in order to select the most appropriate companies to conduct the empirical study. After investigating the market, two multinational and one national companies (Procter \& Gamble, Nestle and Sakr Group) are identified to serve the empirical study in order to achieve results that are more reliable. The first two companies represent 
two of the Top 10 FMCGs Companies in the World 2018; Procter and Gamble is a well-known global organization that has its plants operating all around the world in several countries and its SC management plays a vital role in maintaining this. Nestle, the world's largest supplier of food and beverages, is a global leader in addressing SC management. While the third company (Sakr Group) is a domestic company that currently leads as a food and beverage supplier in the Middle East, with seven major factories and distribution partnerships that not only span the MENA region, but the whole world.

Three phases are carried out to conduct the empirical study as follows:

\section{4-1 Analyzing the SC of the Egyptian FMCGs Sector}

The aim of this phase is to present an overview of each company and its Supply chain by using different data collection methods (primary and secondary) through periodicals, specialized journals, documentations, archival records, interviews (semi-structured) and online references.

In-depth interviews are carried out in this phase to get an overview of each company through briefly outlining what the company does, how it developed historically, what the company's current situation is and what problems it faces. The analysis of the interviews provides an understanding of the companies' supply chain through identifying the main members in the supply chain, analyzing the structural dimensions of their supply chain, determining supply chain classification, and evaluating the challenges facing the organizations internally and externally in the Egyptian market. The interviews' results concluded the main factors affecting forecast accuracy, and especially the FMCGs sector, and finally illustrate the essential KPIs for measuring the integrated SC forecasting.

The interviews are held with specialized managers (Supply and Demand Planning Managers) after submitting an introductory letter to the three companies as a request for the initial acceptance to gain access. The interviews are conducted face-to-face and the duration approximately takes 40 minutes in order to ensure the accuracy and precision of information. 
The results identify the main challenges facing the implementation of the proposed framework on the FMCGs sector in Egypt. The challenges are classified into four main dimensions: lack of trust and commitment between SC partners, inefficient real-time data assumption, lack of confidence in generating sales forecasts, and the power of retailers and wholesalers in collaboration.

The interviewees confirm that trust is a critical factor in raising commitment among SC partners. The presence of trust measurably improves the chances of a successful SC performance. The respondents declare that they trust processes that are transparent and inclusive, more than those tracking down and merging information from different departments (Marketing, Sales, Operations, Finance or HR). One of the main obstacles highlighted by the respondents, which causes a lack of trust, is miscommunication, both internally and externally; internally between departments in sharing accurate information and externally with global deal suppliers, as there are frequent changes in the costs of raw materials, customer demand for product quality, deliveries time and sourcing of raw materials. The instability of demand leads sometimes to re-planning from the beginning to evaluate the economy which is too unstable to put plans regularly.

Inefficient real-time data is another problem as integrated SC forecasting is a "living" process in which forecasts should incorporate the changes across all departments in real-time. If the forecasts do not reflect the latest information, then any decisions the company bases on those forecasts are immediately outdated.

Lack of confidence in generating sales forecasts is another issue and it occurs due to the different targets and goals of each department based on which they set up the upcoming forecasts. For example, the marketing department assumes higher numbers, unlike the sales departments which demands overachieving, whereas the demand planner wants the most ideal numbers compared to the trade manager who needs actual numbers. Different arguments and lack of communication cause a lack of confidence as the forecast seems to be too subjective and based on biased management judgment resulting in incomplete information and potentially outdated forecasts. This uncertainty leads to confusion and mistrust in the forecast. Stakeholders then start looking for alternative 
forecasts that they can confidently base key decisions on. Sometimes, this means building their own models, spreadsheets or local data systems. Other times, it means relying on their experience. While they may feel more confident, they still have no assurance that data and assumptions are correct and up-to-date.

Finally, the power of retailers and wholesalers in collaboration should be considered. System limitations, lack of automation and even collaboration culture are impediments to achieve sustainable retailersupplier collaboration.

The FMCGs sector in Egypt also faces internal and external challenges since there are the complex tariffs and duties and a multilevel distribution system, which all impact the final price of products. Moreover, the respondents added the instability in the Egyptian economic and political conditions as a significant challenge, especially after the Devaluation in 2016 and the announcement of the Central Bank of Egypt (CBE) in a surprise move that it had fully floated the Egyptian pound (EGP). The FMCGs face complexities in managing in-bound logistics, product transfer and taxes, prices of products change and interest rate. The political situation also affects the cost of labor, law and regulation.

\section{4-2 Linking Integrated SC Forecasting in FMCGs Sector to SC Performance}

As illustrated earlier, an exploratory survey capturing collaborative SC forecasting practices and SC performance is conducted with top managers in command of operations and SC. Sixty responses on the survey from six companies in the Egyptian FMCGs sector (P \& G, Johnson and Johnson, Mondelez, Nestle, El-Dawlia for Sweets Trading SAE and AlMansour for International Trade and Distribution) are analysed using a statistical package; SPSS "Statistical Program in the Social Science". 
Table 3: Multiple regression test to study the impact of independent variables on SC forecasting

\begin{tabular}{|l|c|c|c|c|c|c|c|}
\hline \multicolumn{1}{|c|}{ Variables } & B & T & $\begin{array}{c}\text { p- } \\
\text { values }\end{array}$ & R & R2 & F & $\begin{array}{c}\text { p- } \\
\text { values }\end{array}$ \\
\cline { 1 - 5 } (Constant) & 0.116 & 0.256 & 0.799 & 0.470 & 0.221 & 3.786 & 0.02 \\
\cline { 1 - 5 } Information Sharing & 0.270 & 2.466 & 0.01 & & & & \\
\cline { 1 - 4 } Information Quality & 0.211 & 2.104 & 0.04 & & & & \\
\cline { 1 - 4 } $\begin{array}{l}\text { Information } \\
\text { Technology }\end{array}$ & -0.204 & - & 0.2 & & & & \\
\hline
\end{tabular}

Table 4: Simple linear regression of SC forecasting on dependent variables

\begin{tabular}{|l|c|c|c|c|c|c|}
\hline \multicolumn{1}{|c|}{ Variables } & R & R2 & B & F & T & p-values \\
\hline $\begin{array}{l}\text { Impact of SC forecasting on } \\
\text { responsiveness }\end{array}$ & 0.340 & 0.116 & 0.741 & 5.495 & 2.344 & 0.02 \\
\hline $\begin{array}{l}\text { Impact of SC forecasting on } \\
\text { product availability } \\
\text { assurance }\end{array}$ & 0.361 & 0.130 & 0.776 & 6.291 & 2.508 & 0.02 \\
\hline $\begin{array}{l}\text { Impact of SC forecasting on } \\
\text { Cost and Asset } \\
\text { Management }\end{array}$ & 0.307 & 0.095 & 0.627 & 4.385 & 2.094 & 0.04 \\
\hline
\end{tabular}

As illustrated in Tables 3 and 4, the analysis reveals the positive impact of integrated SC forecasting on SC performance and overall performance. The respondents agree on all the factors affecting integrated SC forecasting and their validity. The responses confirm that the implementation of integrated SC forecasting leads to enhancing the responsiveness, reliability, cost and asset management and proves that some of the SC practices flow in the Egyptian FMCGs sector differ from one company to another.

Finally, the survey results prove that there is a non-significant impact of information technology on SC forecasting, which is considered as the most significant challenge in need of fixing and solving in order to enhance the SC performance.

\section{4-3 Verifying the Relationship between Integrated SC Forecasting and SC Performance in the Egyptian FMCGs Sector}

From the analysis of the interviews and questionnaires conducted in the previous two stages, the impact of integrated SC forecasting is approved and its positive impact on the SC performance and on the overall firm performance as well. Although the significant impact on SC performance 
has been confirmed, there are identified challenges that can present a barrier to adopting the proposed framework on the FMCGs sector in Egypt, mainly (lack of trust and commitment between SC partners, inefficient real-time data assumption, lack of confidence in generating sales forecasts, and the power of retailers and wholesalers in collaboration).

The third phase of the empirical study is based on a semi-structured interview developed in line with a data gathering and analysis plan that covered the entire study in order to identify the proposed actions to overcome the challenges facing the implementation of the proposed framework in the Egyptian FMCGs sector. Interviews are conducted with three top management levels in the three companies which were interviewed in the first stage in order to ensure the consistency of results.

The three interviewees declare that every forecasting process can be executed using two extreme approaches - pure analytics on one side and pure insight on the other. Collaborative forecasting combines both approaches by incorporating the best aspects of each. Analytics-based forecasting relies on forecasting "engines" in which statistical and other mathematical models are applied to data to automatically find trends, patterns, seasonality, shifts, correlations, etc. These engines employ analytics that find and extract information from data and that humans could not do easily. In contrast, insight-based forecasting relies exclusively on human judgment and gut-feel. Key stakeholders apply their experience, knowledge of business operations, expectations of customer actions, sense of market conditions, etc. to project future outcomes. Collaborative forecasting software can balance analytics and insight by applying analytics; to find good baseline forecasts, and then adjusting and overriding them based on insight.

Because of ineffective sales forecasting and lack of confidence, companies face the problem of shortage or excess of stock, and hence inefficient operations. Interviewees recommend conducting the forecasts monthly, so in case of increased demand, it would be easy to replan quickly, resulting in increased responsiveness and reliability. 
Interviewees recommend employing an information system to ensure forecast accuracy. This could be a forecast server, such as a "Statistical Analysis System (SAS)", in order to improve sales forecasting. The forecast server allows the optimal demand planning which is important for the FMCGs companies. This is because any inaccuracy in planning will cause a potential delay production. Enterprises Resource Planning (ERP) could also be utilized as a software solution that manages the company's core processes, such as financials, SC, production, manufacturing, engineering, HR activities and more. ERP integrates these processes into one single system, providing real time information across multiple departments so businesses can make data-driven decisions to streamline daily operations, drive efficiencies, manage complexity and grow.

The interviewees agree that the instability in the Egyptian economy and political conditions are a huge challenge. They have strongly approved that real-time data is one of the most powerful catalysts enabling a greater integrated forecasting process. By improving the quality of decisions, real-time data meet a diverse and demanding series of needs across every phase of sales forecasting. Examples include: installing GPS in vehicles to improve their traceability, updating customer database on a regular basis and enhancing the visibility of stock to have a clear view of inventory and location, swift monitoring of order progress and related supply chain activities, along with being able to anticipate the occurrence of any unplanned events in the supply chain.

The three interviewees confirm that the advancement of information technology has increased the ease of information sharing and has provided better methods to share and integrate information. Technological linkages across organizational units as well as up and down the supply chain are particularly critical to sharing information. Different organizations may use various types of hardware, software, data standards and definitions, as well as programming languages and the task of integrating them could be very challenging.

The following table (Table5) demonstrates the main dimensions of the challenges facing the FMCGs sector in adopting integrated SC forecasting along with proposed actions to overcome these challenges and ensure 
that the relationship between SCPs, collaborative forecasting and SC performance is correctly identified and linked.

Table 5: Integrated SC forecasting model adoption challenges and solutions

\begin{tabular}{|c|c|}
\hline $\begin{array}{l}\text { Dimensions of } \\
\text { challenges to adopt } \\
\text { integrated SC }\end{array}$ & Proposed solutions \\
\hline $\begin{array}{l}\text { Lack of trust and } \\
\text { commitment between } \\
\text { SC partners }\end{array}$ & $\begin{array}{l}\text { 1. Allowing each stakeholder to add new information, } \\
\text { propose changes, test scenarios and share insights in a } \\
\text { single, shared system so that their basis and } \\
\text { contributions are tracked, time stamped and } \\
\text { documented for complete openness and transparency } \\
\text { 2. Empowering staff to "own" their day-to-day } \\
\text { responsibilities. } \\
\text { 3. Being open and transparent on key decisions/changes } \\
\text { to business process or procedure } \\
\text { 4. Focusing on some important actions: Share } \\
\text { common/mutual goals } \\
\text { 5. Demonstrating honesty and integrity by delivering } \\
\text { expected performance over time } \\
\text { 6. Acquiring adequate technical proficiency/workforce } \\
\text { skills }\end{array}$ \\
\hline $\begin{array}{l}\text { Inefficient real-time } \\
\text { data assumption }\end{array}$ & $\begin{array}{l}\text { Increasing visibility, enhancing service levels, customer } \\
\text { relationships and skill development } \\
\text { Providing a central forecasting application that pulls in } \\
\text { data from disparate systems spread throughout the } \\
\text { organization and provides mechanisms for key } \\
\text { stakeholders and knowledgeable people to record their } \\
\text { assumptions and link them directly to the forecasts. The } \\
\text { application cannot simply document and store insights in } \\
\text { some spread sheet or database. Instead, assumptions } \\
\text { must be modeled quantitatively and linked to a forecast. } \\
\text { As the assumptions change, the forecasts change in } \\
\text { response. } \\
\text { Upgrading developing countries' overall performance } \\
\text { with the help of new trends of technologies }\end{array}$ \\
\hline $\begin{array}{l}\text { Lack of confidence in } \\
\text { generating sales } \\
\text { forecasts }\end{array}$ & $\begin{array}{l}\text { Providing sales forecast applications that are informed by } \\
\text { actuals and backlog from ERP and connected into demand } \\
\text { planning systems will drive higher adoption across a } \\
\text { company. } \\
\text { Providing one general training academy, offering courses } \\
\text { on sales forecasting approaches } \\
\text { Improving production plan performance by attaining } \\
\text { greater schedule accuracy }\end{array}$ \\
\hline
\end{tabular}




\begin{tabular}{|c|c|}
\hline $\begin{array}{c}\text { Dimensions of } \\
\text { challenges to adopt } \\
\text { integrated SC }\end{array}$ & Proposed solutions \\
\hline $\begin{array}{c}\text { Power of retailers and } \\
\text { wholesalers in } \\
\text { collaboration }\end{array}$ & $\begin{array}{l}\text { Designing displays that work best for the available space } \\
\text { and take into account the retailer's detailed needs } \\
\text { Educating the staff of brands about the sales impact of a } \\
\text { right set up display } \\
\text { Both parties comparing their records of historical } \\
\text { promotion performance, shopper intelligence, and POS } \\
\text { data to make sure they are aligned, permitting for better } \\
\text { goal setting } \\
\text { Suppliers showing activity data, such as time spent in } \\
\text { store and frequency of store visits, to show the retailer } \\
\text { their devotion to flawless retail execution }\end{array}$ \\
\hline $\begin{array}{l}\text { Instability in the } \\
\text { Egyptian economy and } \\
\text { political conditions }\end{array}$ & $\begin{array}{l}\text { Necessary governmental interventions to enhance the } \\
\text { sector's competitive edge } \\
\text { Adopting flexible mechanisms for best practices that suit } \\
\text { the existing situations regarding their environmental and } \\
\text { economic conditions } \\
\text { Providing beneficial industrial and economic } \\
\text { environments to enhance linkages with supply chain } \\
\text { members and adapt easily }\end{array}$ \\
\hline $\begin{array}{l}\text { Insufficient information } \\
\text { technology }\end{array}$ & $\begin{array}{l}\text { Designing software to manage and improve the exchange } \\
\text { of information across various key supply chain partners } \\
\text { to attain such outcomes as just-in-time procurement, } \\
\text { reduction of inventory, increase of manufacturing } \\
\text { efficiency and meet customer needs in a timely way } \\
\text { Investing more in IT applications, for example: Electronic } \\
\text { Data Exchange (EDI), Radio Frequency Identification } \\
\text { (RFID), Bar Code, Electronic Commerce, Decision Support } \\
\text { system, (ERP) package, etc., that are easily applicable in } \\
\text { the restriction of e-risks } \\
\text { Understanding the role and application of IT in managing } \\
\text { and curbing the e-risks of Supply Chain }\end{array}$ \\
\hline
\end{tabular}

\section{5- Conclusion}

This research proposes a framework to investigate the impact of integrated SC forecasting on SC performance. The researchers have conducted an empirical study on three different companies, considering two multinational and one local company, in the Egyptian FMCGs industry to demonstrate the applicability of the research framework.

The results identify (Information Sharing, Information Quality and Information Technology) as the main variables to implement integrated $\mathrm{SC}$ forecasting. The results prove that integrated SC forecasting has a positive impact on the SC performance, and hence on the overall organization performance. However, it faces several challenges and 
barriers in the Egyptian FMCGs sector. The research highlights the insufficient information technology management, lack of information transparency and commitment, inefficient real-time data assumption, lack of confidence in generating sales forecasts, as well as the power of retailers and wholesalers in collaboration, as the main barriers in the Egyptian FMCGs sector. Findings highlight the importance of collaborative forecasting applications and how balancing between analytic and insight forecasts can change the game.

The research provides an original contribution to knowledge by introducing a framework linking integrated SC forecasting to SC performance. The research proposes procedures to identify challenges encountered during the process of adopting SC integrated forecasting which can pave a way for further research, particularly in developing countries. The research can help managers and organizations to identify integrated SC forecasting process and how to enhance it; subsequently this can facilitate improving SC performance and dealing with changes in the organizational performance. The findings of this research should be carefully addressed considering the limitations of empirical research. First, it might be indicated that the analysis has been conducted in a specific geographical area and for one specific sector which is the retail sector (FMCGs). Therefore, the theoretical framework can be applied whether in other countries to be tested on FMCGs or for other sectors than FMCGs. 


\section{References}

Aradhana Gandhi, (2016).Literature Review on Impact of CRM, SRM, Information Sharing and Goal Congruence on Retail-SCM, Indian Journal of Science and Technology, 9(22), DOI: 10.17485/ijst/ 2016/v9i22/95096,

Attaran, Mohsen \& Attaran, Sharmin, (2007). Collaborative supply chain management: The most promising practice for building efficient and sustainable supply chains, Business Process Management Journal. 13. 390-404. 10.1108/14637150710752308.

Ayoub, H.F.; Abdallah, A.B. and Suifan, T.S. (2017). The effect of supply chain integration on technical innovation in Jordan: the mediating role of knowledge management, Benchmarking: An International Journal, 24(3), 594-616.

B.S. Sahay, Ramneesh Mohan, (2003) Supply chain management practices in Indian industry, International Journal of Physical Distribution \& Logistics Management, 33 (7), 582-606, https://doi.org/10.1108/ 09600030310499277.

Bongsug (Kevin) Chae (2009). Developing key performance indicators for SC: an industry perspective, SC Management: An International Journal, 14 (6), 422-428, https://doi.org/10.1108/1359854 0910995192.

Bowersox, D.J.; Close, D.J. and Stank, T.P. (2003). How to master crossenterprise collaboration, SCM Review, 7 (4), 18-27.

C. Marinagia, P. Trivellas, P. Reklitis, (2015). Information Quality and SC Performance: The Mediating Role of Information Sharing, Procedia - Social and Behavioral Sciences 175 (2015) 473 - 479

Can Eksoz; S. Afshin Mansouri; Michael Bourlakis (2014). Collaborative forecasting in the food SC: A conceptual framework, Int. J. Production Economics 158 (2014) 120-135. 
Chang Won Lee, IkWhan G. Kwon, Dennis Severance, (2007) Relationship between SC performance and degree of linkage among supplier, internal integration, and customer", SC Management: An International Journal, 12 (6), 444-452, https://doi.org/ 10.1108/13598540710826371.

Chen, H.; Daugherty, P.J. and Landry, T.D. (2009), Supply chain process integration: a theoretical framework, Journal of Business Logistics, 30(2), 27-46.

Chwen Sheu; HsiuJu Rebecca Yen; Bongsug Chae (2006). Determinants of supplier rand retailer collaboration: evidence from an international study, International Journal of Operations \& Production Management, 26(1), 24-49, https://doi.org/10.1108/014 43570610637003.

Colicchia, C.; Creazza, A.; Noè, C. and Strozzi, F. (2019).Information sharing in supply chains: a review of risks and opportunities using the systematic literature network analysis (SLNA), Supply Chain Management, 24 (1), 5-21. https://doi.org/10.1108/SCM-012018-0003

Dag Näslund, Hana Hulthen, (2012). SCM integration: a critical analysis, Benchmarking: An International Journal, 19 (4/5), 481-501, https:// doi.org/10.1108/14635771211257963

Donlon, J.P. (1996). Maximizing value in the SC, Chief Executive, 117, 5463.

Douglas M. Lambert, A. Michael, John T. Gardner (2004). SC Partnerships: Model Validation And Implementation, Journalof Business Logistics, $25,(2)$

Elgazzar, S.; Tipi, N.S.; Hubbard, N.J. and Leach, D.Z. (2011a). Linking supply chain operations' performance to the company's financial strategy: a case study of an Egyptian natural bottled water company. In: Proceedings of the 16th International Symposium on Logistics (ISL 2011), Berlin, Germany, 173-Marilyn. 
Elgazzar, Sara H. (2013). Enhancing the Company's Financial Performance of Supply Chain Operations: A Case Study of an Egyptian Manufacturing Company. Doctoral thesis, University of Huddersfield

English, L.P. (1999), Improving Data Warehouse and Business Information Quality, Wiley, New York, NY.

Gary Graham, Glenn Hardaker, (2000). upply-chain management across the Internet, the international Journal of Physical Distribution \& Logistics Management, 30 (3/4), 286-295

Gordon Stewart, (1995). SC performance benchmarking study reveals keys to SC excellence, Logistics Information Management,8(2), 3844 https://doi. org/10.1108/09576059510085000.

Gunasekaran, Angappa \& Patel, Chintan \& Tirtiroglu, Ercan. (2001). Performance Measures and Metrics in a Supply Chain Environment International Journal of Operations \& Production Management. 21. 71-87. 10.1108/01443570110358468.

Helena Forslund, Patrik Jonsson, (2007). The impact of forecast information quality on SC performance, International Journal of Operations \& Production Management, 27 (1), 90-107, https://doi.org/10.1108/01443570710714556

Ing-Long Wu, Cheng-Hung Chuang, Chien-Hua Hsu, (2014). Information sharing and collaborative behaviours in enabling SC performance: A social exchange perspective, Int. J. Production Economics 148 ,122-132 Innovation in Jordan: the mediating role of knowledge management, Benchmarking: An International Journal, 24 (3), 594616

Khanuja, Anurodh and Jain, Rajesh, (2019). Supply chain integration: a review of enablers, dimensions and performance, Benchmarking: An International Journal. ahead-of-print. 10.1108/BIJ-07-20180217. 
LeMay, Stephen \& Helms, Marilyn \& Kimball, Bob \& Mcmahon, Dave, (2017). Supply Chain Management: The Elusive Concept and Definition, The International Journal of Logistics Management. 28. 10.1108/IJLM-10-2016-0232.

Li, G.; Yang, H.; Sun, L.;Sohal, A.S. (2009). The impact of IT implementation on SC integration and performance, International Journal of Production Economics 120 (1), 125-138

Li, S.; Ragu-Nathan, B.; Ragu-Nathan, T.S. and Subba Rao, S. (2006), The impact of SCM practices on competitive advantage and organizational performance, Omega, 34 (2), 107-124.

Lindau, R. and Lumsden, K., (1993). Disturbance Absorption Actions Used in Material Flow Systems - A Pilot Study, Department of Transportation and Logistics, Chalmers University of Technology, Go"teborg.

M. Helms, Lawrence P. Ettkin, Sharon Chapman. (2000). SC forecasting Collaborative forecasting supports SC management, Business Process Management Journal, 6 (5), 392-407, https://doi.org/10.1108/14637150010352408.

Mahdi Rezaei, Mohsen Akbarpour Shirazi, Behrooz Karimi, (2017). IoTbased framework for performance measurement: A real-time SC decision alignment, Industrial Management \& Data Systems, 117(4), 688-712, https://doi.org/10.1108/IMDS-08-2016-0331

Mark Barratt, (2004). Understanding the meaning of collaboration in the SC, SC Management: An International Journal, 9 (1), 30-42, https://doi.org/10.1108/13598540410517566

Mikihisa Nakano, (2009). Collaborative forecasting and planning in SCs: The impact on performance in Japanese manufacturers, International Journal of Physical Distribution \& Logistics Management, 39 (2), 84-105, https:// doi.org/ $10.1108 / 09600030910942377$. 
Moberg, C.R.; Cutler, B.D.; Gross, A. and Speh, T.W. (2002). Identifying antecedents of information exchange within supply chains, International Journal of Physical Distribution \& Logistics Management, 32 (9), 755-70

Okongwu, Uche \& Brulhart, Franck \& Moncef, Btissam. (2015). Causal linkages between supply chain management practices and performance: A balanced scorecard strategy map perspective. Journal of Manufacturing Technology Management. 26. 678-702. 10.1108/ JMTM-01-2013-0002.

Prajogo, D. and Olhager, J. (2012). SC integration and performance: the effects of long-term relationships, information technology and sharing, and logistics integration, International Journal of Production Economics, 135 (1), 514-522

Robert B Handfield; Paul D Cousins; Benn Lawson; Kenneth J Petersen. (2011). Breakthrough scanning, supplier knowledge exchange, and new product development performance, Journal of Product Innovation, 28 (8), 930-942

Rong $\mathrm{Lu}$, (2015). A study to examine the Importance of Forecast Accuracy to SC performance, the contributing Factors and the Improvement Enablers in Practice

Tan, K.C. (2001). A framework of SCM literature, European Journal of Purchasing \& Supply Management, 7, 39-48.

Tarek Sadraoui, and Nejib Mchirgui (2014). SCM Optimization within Information System Development, International Journal of Econometrics and Financial Management, 2(2)

Togar M. Simatupang, Ramaswami Sridharan, (2005). An integrative framework for supply chain collaboration, The International Journal of Logistics Management, 16 (2), 257-274, https://doi.org/10.1108/095740905 10634548. 
Veera Pandiyan Kaliani Sundram, Abdul Razak Ibrahim, V.G.R. Chandran Govindaraju, (2011). Supply chain management practices in the electronics industry in Malaysia: Consequences for supply chain performance, Benchmarking: An International Journal, 18 (6), 834855.

Yang, T.-M., \& Maxwell, T.A. (2011). Information-sharing in public organizations: A literature review of interpersonal, intraorganizational and inter-organizational success factors, Government Information Quarterly 28, 164-175. 


\section{تأثير تكامل التنبؤ بسلسلة الإمداد على أداء سلسلة الإمداد: دراسة تطبيقية على قطاع السلع الاستهلاكية سريعة الحركة في مصر الإمراع

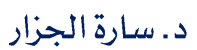 \\ مهيرة مصطفى عبد الشافى}

ملخص البحث باللغة العربية

أصـبحت المنظمات تدرك أن نجاح واســدامة أعمالها تعتمد بشــدة على التكامل مع مورديها وعملائها؛ خاصــة فيما يتعلق

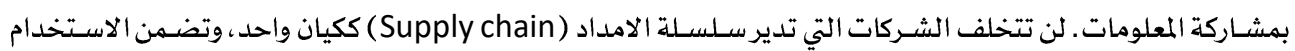

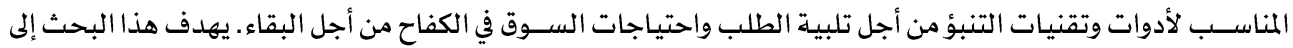

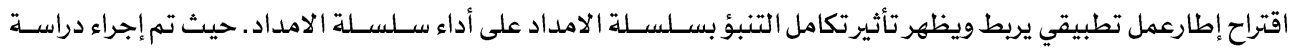

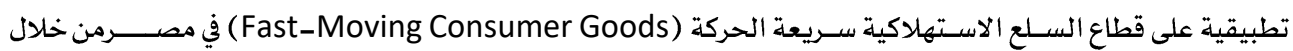
شـركتين متعددى الجنسـيات : شـركة بروكتروغامبل ونسـتله ، بالاضـافة الى شـركة وطنية واحدة : مجموعة صــر. بدأت الدراسة أولا بمقابلات شخصية شبه منظمة لتوصيف سلسلة امداد السلع الاستهلاكية سريعة الحركة وتحليل خصائل المائصها في السوق المصـري ـثم تم تصميم وتنفيذ استقصاء لدراسة العلاقة بين تكامل التنبؤ بسلسلة الامداد وأداء سلسلة الامداد، وكذلك تحديد اهم المتغيرات التي تعززتكامل التنبؤ بسلسلة الامداد في قطاع السلع الاستهلاكية سريعة الحركة المصــرية.

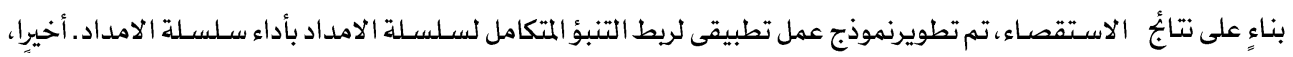

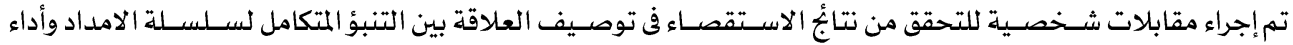

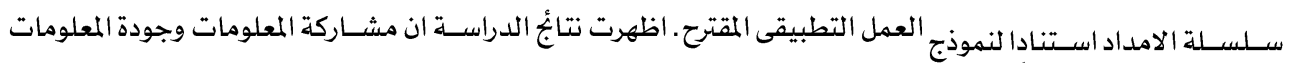

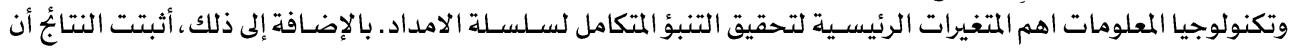

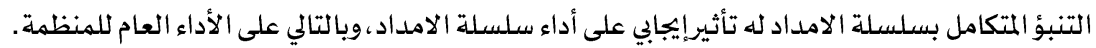

الكلمات الدالة: التتبؤ المتكامل بسـلسـلة الامداد؛ أداء سـلسـلة الامداد؛ تكامل سـلسـلة الامداد؛ قطاع السـلع الاسـتهلاكية سريعة الحركة ؛ مصر العرات التبؤر

\section{Suggested Citation according to APA Style}

Abdel-shafie, M. M. and Elgazzar, S. H. (2021). Investigating the Impact of Integrated Supply Chain Forecasting on the Supply Chain Performance: Empirical Study from the FMCGs Sector in Egypt. Journal of Alexandria University for Administrative Sciences, Faculty of Commerce, Alexandria University 58(2), 261 - 289. 


\section{مجلة جامعة الإسكندريـة للعلوم الإدارية متاحة على: بوابة بنك المعرفة المصري}

Egyptian Knowledge Bank (EKB)

\section{https://acjalexu.journals.ekb.eg/}

للسادة الراغبين في النشر في:

مجلة جامعة الإسكندرية للعلوم الإدارية

(مجلة كلية التجارة للبحوث العلمية سابقا)

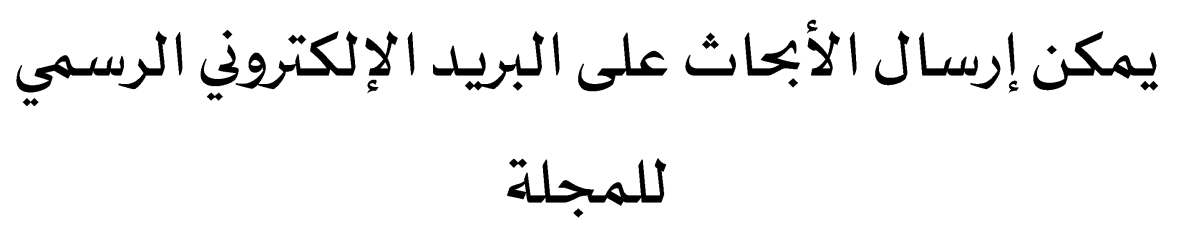

JAS.AU@alexu.edu.eg

تقييم المجلة في لجان الترقية 6.5 درجة 